\title{
Isolation, biochemical characterization, and phylogeny of a cellulose-degrading ruminal bacterium
}

\author{
Aislamiento, caracterización bioquímica y filogenia de una bacteria ruminal degradadora de celulosa \\ Isolamento, caracterização bioquímica e filogenia de uma bacteria ruminal degradante de celulose
}

Lorena Luna ${ }^{1}$, Dra; David Hernández ${ }^{1 *}$, Dr; Hilda V Silva ${ }^{2}$, Dra; Mario A Cobos ${ }^{1}$, PhD; Sergio S González ${ }^{1}$, PhD; César Cortez ${ }^{1}$, PhD; René Pinto ${ }^{3}$, Dr; Efrén Ramírez ${ }^{1}$, Dr; Juan M Pinos ${ }^{4}$, Dr; Juan M Vargas ${ }^{5}$, Dr.

${ }^{1}$ Postgrado de Ganadería, Colegio de Postgraduados, 56230, Montecillo, Estado de México, México.

${ }^{2}$ Postgrado en Producción de Semillas, Colegio de Postgraduados, 56230, Estado de México, México.

${ }^{3}$ Facultad de Ciencias Agronómicas, Universidad Autónoma de Chiapas, 30475, Chiapas, México.

${ }^{4}$ Centro de Biociencias, Universidad Autónoma de San Luis Potosí, 78000, San Luis Potosí, México.

${ }_{5}^{5}$ Área de Sistemas de Producción Agropecuarios, Universidad Autónoma Metropolitana-Iztapalapa, 09340, Ciudad de México, México.

(Received: January 26, 2018; accepted: August 24, 2018)

doi: 10.17533/udea.rccp.v32n2a05

\begin{abstract}
Background: The isolation of cellulolytic bacteria, which hydrolyze cellulose to cellobiose and glucose, can provide useful information about rumen diversity. Objective: To identify and characterize a microorganism capable of hydrolyzing cellulose, isolated from a cow rumen. Methods: Anaerobic culture techniques were used for isolating cellulose-degrading rumen bacteria. Congo red staining was used to evaluate $\beta$-D-glucanase activity, and carbohydrate fermentation pattern was obtained with the kit API 50CHB/E. DNA extraction was performed and the 16S rDNA gene was amplified using 8F (5'-AGA GTT TGA TCC TGG CTC AG-3'), and 1492R (5' GGT TAC CTT GTT ACG ACT T 3') primers. The phylogenetic tree was reconstructed with the algorithm of maximum parsimony (bootstrap 5000), and 16S rDNA sequence was deposited in the NCBI database (accession number: KM094184). Results: The isolated bacterium showed cellulolytic activity detected with Congo red; besides, glycerol, ribose, xylose, sucrose, galactose and glucose were fermented by this bacterium. However, biochemical tests did not identify the bacteria because no match was found at database
\end{abstract}

a To cite this article: Luna L, Hernández D, Silva HV, Cobos MA, González SS, Cortez C, Pinto R, Ramírez E, Pinos JM, Vargas JM. Isolation, biochemical characterization, and phylogeny of a cellulose-degrading ruminal bacterium. Rev Colomb Cienc Pecu 2019; 32(2):117-125.

* Corresponding author: David Hernández Sánchez. Posgrado de Ganadería, Colegio de Postgraduados, 56230, Montecillo, Estado de México, México. Tel.: +525959520279. E-mail: sanchezd@colpos.mx 
of API WEB Software. The phylogenetic inference indicated that this bacterium belongs to Shigella genus, with 98\% maximal identity respect to the other taxonomic species. Conclusions: Phylogenetic analysis of 16S rRNA genes showed that the rumen isolated bacterium was a member of the genus Shigella, which, under mesophilic conditions, is an interesting candidate for obtaining oligosaccharides from lignocellulosic biomass.

Keywords: cellulolytic, fermentation, monophyletic, rumen, Shigella.

\section{Resumen}

Antecedentes: El aislamiento de las bacterias celulolíticas, que hidrolizan la celulosa a celobiosa y glucosa, proporciona valiosa información sobre la diversidad del rumen. Objetivo: Identificar y caracterizar un microorganismo capaz de hidrolizar celulosa, aislado de un rumen vacuno. Métodos: Se utilizaron técnicas de cultivo anaeróbico para aislar bacterias ruminales que degradan celulosa. La tinción con rojo Congo se usó para evaluar la actividad $\beta$-D-glucanasa y el patrón de fermentación de carbohidratos se obtuvo con el kit API 50CHB/E. Se realizó la extracción de DNA y se amplificó el gen de $16 \mathrm{~S}$ rDNA utilizando los cebadores 8F (5'-AGA GTT TGA TCC TGG CTC AG-3'), y 1492R (5' GGT TAC CTT GTT ACG ACT T 3'). El árbol filogenético se reconstruyó con el algoritmo de máxima parsimonia (replicas 5000) y la secuencia 16S rDNA se depositó en la base de datos del NCBI (número de acceso: KM094184). Resultados: La bacteria aislada mostró actividad celulolítica detectada con la tinción de rojo Congo; además, esta bacteria fermenta glicerol, ribosa, xilosa, sacarosa, galactosa y glucosa. Sin embargo, las pruebas bioquímicas no permitieron identificar a la bacteria aislada, por no encontrar coincidencias en la base de datos del software API WEB. La inferencia filogenética indicó que esta bacteria pertenece al género Shigella, con $98 \%$ de identidad máxima respecto a las otras especies taxonómicas. Conclusiones: El análisis filogenético del gen 16S rRNA mostró que la bacteria aislada del rumen es un miembro del género Shigella que, en condiciones mesófilas, es un candidato interesante para obtener oligosacáridos a partir de biomasa lignocelulósica.

Palabras clave: celulolítica, fermentación, monofilético, rumen, Shigella.

\section{Resumo}

Antecedentes: As bactérias celulolíticas hidrolizam a celulosa em celobiose e glicose, e o isolamento desses microrganismos fornece informações sobre a diversidade do rúmen. Objetivo: Identificar e caracterizar um microorganismo isolada do rúmen de uma vaca, com capacidade para hidrolisar a celulose. Métodos: Técnicas de cultura anaeróbica foram utilizadas para isolar bactérias ruminais que degradam a celulose. A atividade $\beta$-D-glucanase foi mostrada utilizando mancha de vermelho Congo, e o padrão de fermentação de carbohidratos foi obtida com o kit API 50CHB/E. A extracção foi realizada de DNA e amplificou-se os genes 16S rDNA utilizando os iniciadores 8F (AGA GTT TGA 5'-TCC TGG CTC AG-3'), e 1492R (5' CTT GGT TAC GTT ACG TCA T 3'). A árvore filogenética foi reconstruída com o algoritmo de máxima parcimônia (réplicas 5000). A sequência de rDNA 16S foi depositada no banco de dados do NCBI (número de acesso: KM094184). Resultados: O isolado mostrou uma atividade celulolítica com coloração vermelho Congo; además esta bactéria fermentação de glicerol, ribose, xilose, sacarose, galactose e glicose. No entanto, com as provas bioquímicas não se identificou a bactérias isolada, já que não se encontrou na base de dados do software API WEB. A inferência filogenética indicou que esta bactéria pertence ao género Shigella, com $98 \%$ de identidade de máximo respeito para outras espécies taxonômicas. Conclusão: A análise filogenética do gene 16S rRNA mostrou as bactérias isoladas do ambiente ruminal como um membro do género Shigella, que condições mesofilicas é um candidato atraente para obter oligossacarídeos da biomassa lignocelulósica.

Palavras-chave: celulolítica, fermentação, monofilético, rúmen, Shigella.

\section{Introduction}

Cellulose, a major component of plant biomass, is degraded within the rumen by several bacteria (Dias et al., 2017), fungi (Boots et al., 2013) and protozoa (Newbold et al., 2015). This biomass is hydrolyzed to cellobiose and glucose by cellulolytic microorganisms (Guzman et al., 2016); some anaerobic cellulolytic bacterial strains have developed an efficient enzymatic strategy known as cellulosome (Artzi et al., 2016). Anaerobic ruminal mesophilics digest cellulose by adhering to vegetal fiber (Slutzki et al., 
2013). Ruminococcus albus and $R$. flavefaciens use cellulosomes, pili proteins (Rakotoarivonina et al., 2005) and glicocalix containing extracellular polymeric substances (Weimer et al., 2006), and the catalytic part of the cellulosome includes cellulases, xylanases and pectinases that work synergistically to degrade the complex molecules of the cell wall (Artzi et al., 2016). Microorganisms with these characteristics have potential for the industry of cellulosic-biofuel production since the high cost of converting biomass to sugars is the main obstacle for developing this industry (Venkatesh, 2014; Zhivin et al., 2017).

However, relatively few rumen bacteria have been identified as primary degraders of plant fiber (Flint and Bayer, 2008; Flint et al., 2008). Isolation of these microorganisms can provide useful information about diversity of the ruminal habitat, which would allow identification of fibrolytic enzymes with potential use as forage additives.

Fibrobacter and Ruminococcus are the two genera of ruminal bacteria reported with cellulolytic activity (Wilson, 2011), and not all cellulolytic species have been identified so far. However, molecular analyzes are helping to reveal which phylogenetic groups contribute to fiber degradation (Flint et al., 2008). Wang et al. (2011) reported the isolation and characterization of Shigella flexneri, G3 strain in ruminal liquid. This strain efficiently converted sugars from cellulose as carbon source under mesophilic conditions; thus, it is an attractive candidate for obtaining high yields of oligosaccharides from lignocellulosic biomass. Therefore, the objective of this study was to identify and characterize a microorganism isolated from a cow rumen, capable of hydrolyzing cellulose.

\section{Materials and methods}

\section{Ethical considerations}

The cow used in this study was cared for according to the standards of the Mexican Council on Animal Care (NOM-062-ZOO, 1999).

\section{Isolation of cellulolytic bacteria}

This isolation was performed at the Ruminal Microbiology Laboratory, Colegio de Postgraduados,
Montecillo, Estado de México. Briefly, $300 \mathrm{~mL}$ of fresh ruminal liquid were collected from the middle ventral part of the rumen of a Holstein cow $(520 \mathrm{~kg}$ body weight and fed on grassland of Lolium perene L.) using a sterile ruminal cannula (Mateo-Sánchez et al., 2002). A sample of filtered ruminal liquid (1 mL) was inoculated in an anaerobic selective media (ASM) (Cobos, 1995).

The culture medium ASM $(100 \mathrm{~mL})$ was composed of $47.9 \mathrm{~mL}$ distilled water, $30 \mathrm{~mL}$ of clarified ruminal fluid [filtrated in a triple gauze and centrifuged at $12,857 \mathrm{x} g$ for $15 \mathrm{~min}$ at $4{ }^{\circ} \mathrm{C}$, and sterilized at 121 ${ }^{\circ} \mathrm{C}$ for 15 min at 15 psi in an autoclave (Felisa, FE397, Mexico)]. Five milliliters of mineral solution I [6 $\mathrm{g} \mathrm{K}_{2} \mathrm{HPO}_{4}$ (Sigma, St Louis, MO, USA) in 1,000 $\mathrm{mL} \mathrm{H}_{2} \mathrm{O}$ ]. Besides, $5.0 \mathrm{~mL}$ of mineral solution II [6 $\mathrm{g} \mathrm{KH}_{2} \mathrm{PO}_{4}$ (Sigma, St Louis, MO, USA), $6 \mathrm{~g}$ $\left(\mathrm{NH}_{4}\right) \cdot 2 \mathrm{SO}_{4}$ (Sigma, St Louis, MO, USA), $12 \mathrm{~g} \mathrm{NaCl}$ (Sigma, St Louis, MO, USA), $2.45 \mathrm{~g} \mathrm{MgSO}_{4}$ (Sigma, St Louis, MO, USA), and $1.6 \mathrm{~g} \mathrm{CaCl}_{2}-\mathrm{H}_{2} \mathrm{O}$ (Sigma, $\mathrm{St}$ Louis, $\mathrm{MO}, \mathrm{USA}$ ) in $1,000 \mathrm{~mL} \mathrm{H}_{2} \mathrm{O}$ ]. Two milliliters of $8 \% \mathrm{Na}_{2} \mathrm{CO}_{3}$ solution $\left[8 \mathrm{~g} \mathrm{Na}_{2} \mathrm{CO}_{3}\right.$ (Sigma, $\mathrm{St}$ Louis, MO, USA) in $100 \mathrm{~mL}$ distilled water] and 2 mL sulfide-cysteine solution [2.5 g L-cysteine (Sigma, St Louis, MO, USA) dissolved in $15 \mathrm{~mL} \mathrm{NaOH} 2 \mathrm{~N}$ (Meyer, Tlahuac, Mexico City, Mexico). In addition, $2.5 \mathrm{~g} \mathrm{Na}_{2} \mathrm{~S}-9 \mathrm{H}_{2} \mathrm{O}$ (Meyer, Tlahuac, Mexico City, Mexico)], $0.2 \mathrm{~g}$ tripticase peptone (Biosciences, San Jose, CA, USA), 0.1 g yeast extract (Sigma, St Louis, MO, USA), and $0.1 \mathrm{~mL}$ resazurin (Sigma, St Louis, MO, USA). Nine milliliters of sterile ASM were added to sterile tubes $(18 \times 150 \mathrm{~mm})$ containing a strip of Whatman paper No. 541 (3x30 mm) (Sigma, St Louis, $\mathrm{MO}, \mathrm{USA})$ as a sole carbon source.

After $48 \mathrm{~h}$ incubation at $38{ }^{\circ} \mathrm{C}$, Whatman paper was removed and inoculated in a sterile ASM, and the process was repeated twice following the same incubation conditions. All the procedures were performed under sterile conditions in a biological safety cabinet (Labconco, Purifier Class II model, Kansas City, MO, USA) with 5\% $\mathrm{CO}_{2}$. Petri dishes (Thomas Scientific, Swedesboro, NJ, USA) were used to prepare the solid culture media (SCM) with the same components of the ASM; additionally, bacteriological agar (15 g/L) (Sigma, St Louis, MO, USA) and carboxymethylcellulose $(0.28 \mathrm{mg} / 100 \mathrm{~mL})$ (Sigma, St Louis, MO, USA) was added as the sole 
source of carbon (Cobos, 1995). The SCM were inoculated with the last recovered culture grown in ASM, sealed and incubated at $38^{\circ} \mathrm{C}$ for $72 \mathrm{~h}$. Based on visual inspection of colony morphology, such as color, shape and elevation, colonies with similar morphology were selected and transferred to liquid and solid media (eight times).

Inoculation of culture media and examination of samples were carried out in an Anaerobic chamber (Plas Labs, Lansing, MI, USA), and the incubation of culture in an anaerobic jar (2.5 L AnaeroJar, Oxoid, Basingstoke, Hampshire, UK) provided with AnaeroGen (Oxoid, Basingstoke, Hampshire, UK). Gram staining was performed after each procedure, using an optical microscope Axiostar Zeiss (BioMedical Instruments, Zur Schoenen Aussicht, Zoellnitz, Germany). After massive production in liquid media, purity of the culture was verified with samples observed in the optical microscope (Axiostar Zeiss, BioMedical Instruments, Zur Schoenen Aussicht, Zoellnitz, Germany) and Gram stain; subsequently, the pure culture was lyophilized at $-50^{\circ} \mathrm{C}$ and $0.135 \mathrm{mBar}$ (Labconco Freezone, Kansas, City, MO, USA) and preserved for further use.

\section{Cellulase activity}

The lyophilized culture (strain) was activated by adding $0.1 \mathrm{~g}$ of the lyophilized in $9.9 \mathrm{~mL}$ sterile culture medium (ASM) containing carboximethyl cellulose as the sole carbon source. After $3 \mathrm{~h}$ of the culture hydrated, $10^{-4}, 10^{-5}$ and $10^{-6}$ dilutions were performed and then a cross-stripe seeding was carried out in Petri dishes that contained SCM, using a sterile bacteriological loop and incubating at $38^{\circ} \mathrm{C}$ for $72 \mathrm{~h}$ in an anaerobic environment previously described. After 10 days of growing in solid media (SCM), single colonies were randomly selected and stained with Congo red solution $(1 \mathrm{mg} / \mathrm{mL})$ for $15 \mathrm{~min}$. The dye was washed with $\mathrm{NaCl} 0.1 \mathrm{M}$ solution. Bacteria making haloes around their colonies were isolated as cellulolytic anaerobes.

\section{Biochemical identification}

The lyophilized culture was activated as mentioned previously in the liquid media (ASM) containing carboximethyl cellulose as the sole carbon source.
A $1 \mathrm{~mL}$ sample of this suspension was grown in ASM media for $48 \mathrm{~h}$ at $39^{\circ} \mathrm{C}$, verifying to reach optimal turbidity ( $\left.1 \times 10^{8} \mathrm{UFC} \mathrm{mL}\right)$ according to the methodology described by Ley de-Coss et al. (2013). After reaching optimal turbidity an API 50CHB/E (BioMérieux, Marcy l'Etoile, France) bulb was resuspended with $1 \mathrm{~mL}$ of culture. The carbohydrate fermentation pattern was assessed in an incubation chamber (Riossa EO71, Mexico DF, Mexico), following manufacturer instructions. Test strips were incubated $24 \mathrm{~h}$ at $38^{\circ} \mathrm{C}$ and results were analyzed using API WEB software (API 50 CHB v.4.0).

Strain identification and nucleotide accession number

Genomic DNA extraction and molecular biology methods were carried out according to Hatfull and Jacobs (2014) protocols. The extracted DNA was used as template for PCR amplification of the $16 \mathrm{~S} r$ DNA gene, using the primers 8F (5'-AGA GTT TGA TCC TGG CTC AG-3') and 1492R (5'-GGT TAC CTT GTT ACG ACT T- 3'). PCR was performed according to Valledor et al. (2014). The reaction mixtures $(25 \mu \mathrm{L})$ contained $5 \mu \mathrm{L}$ PCR buffer 5x (Promega, Madison, WI, USA), $2.5 \mathrm{mM}$ deoxynucleoside triphosphate (dNTP), $10 \mathrm{pmol} / \mu \mathrm{L}$ forward and reverse primers, $0.035 \mathrm{U}$ of Taq DNA Polymerase (GoTaq ${ }^{\circledR}$ DNA, $5 \mathrm{U} ; 0.08 \mathrm{U} / \mu \mathrm{L}$; Promega, Madison, WI, USA), and $100 \mathrm{ng}$ template DNA. The samples were amplified using a Bio-Rad DNA Engine with the following thermal profile: $95^{\circ} \mathrm{C}$ for $2 \mathrm{~min}, 30$ cycles at $95^{\circ} \mathrm{C}$ for $2 \mathrm{~min}, 57^{\circ} \mathrm{C}$ for $1 \mathrm{~min}, 72^{\circ} \mathrm{C}$ for $3 \mathrm{~min}$, and finally $75^{\circ} \mathrm{C}$ for $5 \mathrm{~min}$. The PCR-amplified 16S rDNA was purified (Wizard SV gel and PCR Cleand VP-System; Promega, Madison, WI, USA) and its size was verified by low-melting point agarose electrophoresis (EC Maxicell Primo EC 340, Thermo Fisher Scientific, Waltham, MA, USA) using TAE as running buffer. Staining solution SYBR Green (Invitrogen, Carlsbad, CA, USA) was used for UV visualization of DNA, using a KODAK transiluminator (Gel Logic 100 Imaging System, 365 nm; Eastman Kodak Company, Rochester, NY, USA).

Sequencing was performed at Seeds Biotechnology Laboratory, Colegio de Postgraduados, Montecillo, Estado de Mexico. For each reaction, $1.8 \mu \mathrm{L}$ of Buffer BigDye Terminator v3.1 (Applied Biosystems, 
Foster City, CA, USA) and $2 \mu \mathrm{L}$ of each sample were placed in the sequencing plate using a Genetic Analyzer 3130 (Applied Biosystems, Foster City, CA, USA). The BioEdit Sequence Alignment program (v.7.0.9.0) was used to construct the consensus sequences. The nucleotide sequences were compared by BLASTN program (http://www.ncbi.nlm.nih.gov/ BLAST/). Alignment was carried out using ClustalW (MEGA Program, v.6.0). Phylogenetic dendograms were constructed using bootstrap analysis of 5,000 replicates. The $16 \mathrm{~S}$ rDNA sequence generated from bacterial isolate was deposited into NCBI database under accession number KM094184.

\section{Results} strain

Morphology and cellulolytic activity of the isolated

The bacterial strain isolated was a Gramnegative coco bacillus (Figure 1), which forms beige, circular, smooth edges and convex colonies. Bacterial cellulolytic activity based on Congo red staining method was evidenced by the formation of halos (Figure 2) around their colonies due to i $\beta$-Dglucanase activity.

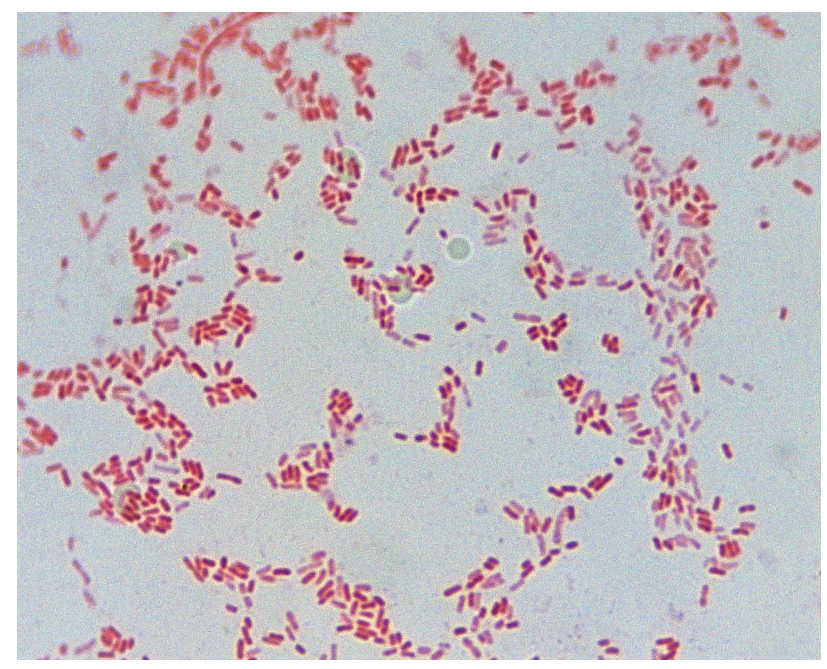

Figure 1. Morphology and Gram staining of the isolated strain.

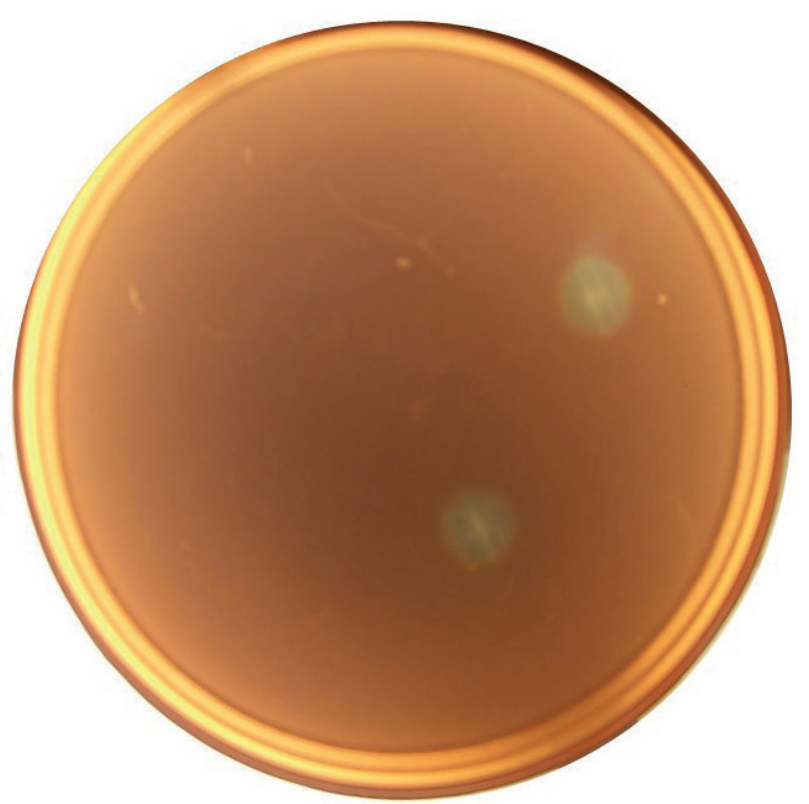

Figure 2. Plate based cellulolytic activity screening of isolates showing zones of clearance around the colonies after activity staining with Congo red solution.

\section{Biochemical identification}

Microorganisms have a fermentation pattern that allow to characterize and identify bacterial genera. The result obtained in our study with the enzimatic gallery API $50 \mathrm{CHB} / \mathrm{E}$ was integrated by API WEB Software (Table 1). However, no matching was found in the database.

\section{Phylogeny}

The phylogenetic tree based on $16 \mathrm{~S}$ rDNA sequence is shown in Figure 3. This result allows confirming that the ruminal isolated bacteria belongs to Shigella genus, sharing $98 \%$ similarity to other species from this taxon and phylogenetic inference indicates a reliability of 64 with this genus. However, this is an unrecognized species within the genus Shigella, based on the assumption that strains with less than $98 \%$ of identity are not related at the bacterial species level. 
Table 1. API $50 \mathrm{CHB} / \mathrm{E}$ results and preliminary identification within genera Shigella.

\begin{tabular}{lcccc}
\hline Substrate utilization & Value & Substrate utilization & Value & Substrate utilization \\
\hline Glycerol & + & Salicin & - & D-Arabitol \\
Erythrol & - & D-Cellobiose & - & L-Arabitol \\
D-arabinose & - & D-Maltose & + & Gluconate \\
L-arabinose & + & Lactose & + & 2-Keto-Gluconate \\
D-ribose & + & Melibiose & + & 5-Keto-Gluconate \\
D-Xilose & + & Sucrose & - & Raffinose \\
L-Xilose & - & Trehalose & + & Starch \\
Adonitol & + & Inulin & - & - \\
b-Methyl-D-xiloside & - & G- Acetyl Glucosamine & + & Glycogen \\
D- Galactose & + & Melezitose & - & 1-Methyl-D-Glucoside \\
D-Glucose & + & Rhamnose & Gentiobiose \\
D-Fructose & + & Sorbose & + & - \\
Amygdaline & - & D-Mannose & - & D-Turanose \\
Arbutin & - & Dulcitol & Xylitol \\
Esculin & - & Inositol & D- Mannitol
\end{tabular}

+ : Positive bacterial activity to the substrate.

-: Negative bacterial activity to the substrate.

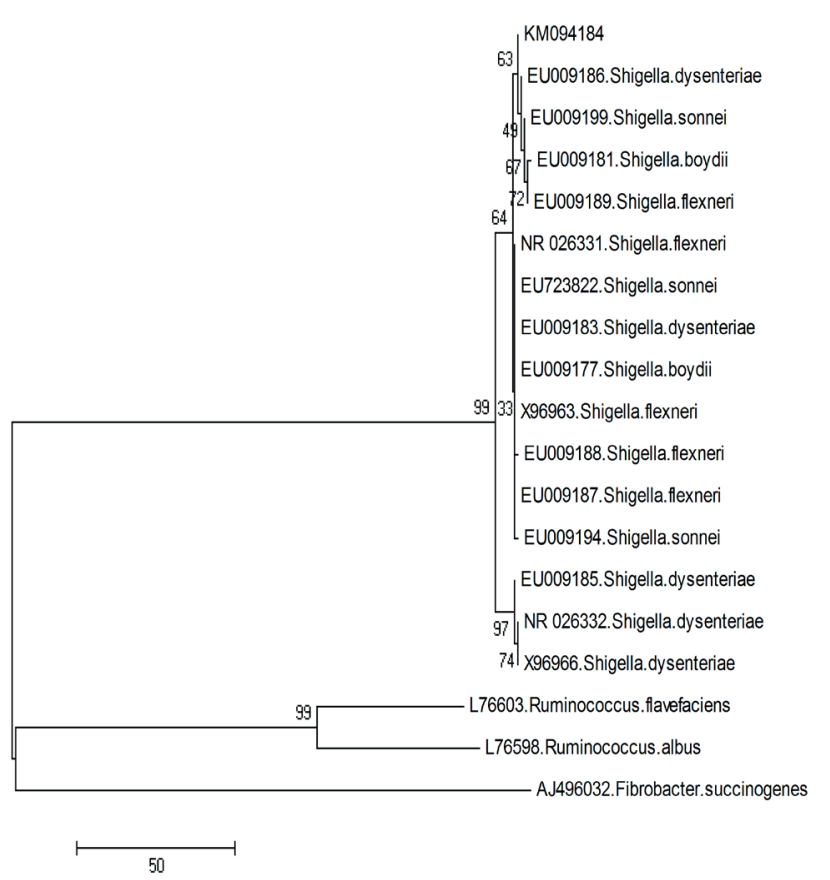

Figure. 3. Phylogenetic tree of the isolated strain and other known Shigella strains based on 16S rDNA gene sequences. The numbers along branches indicate bootstrap values $(5,000$ replicates). Nucleotide sequence for $16 \mathrm{~S}$ rRNA of the isolated microorganism is available at NCBI with the access number KM094184.

\section{Discussion}

The ruminal cellulolytic bacteria most reported in the literature are Fibrobacter succinogenes, Ruminococcus flavefaciens and Ruminococcus albus (Denman and McSweeney, 2015). There are also reports for Pseudobutyrivibrio, Butyrivibrio, Streptococcus, Enterococcus, Anaerovibrio, Selenomonas, Shaccharofermentans and Actinomyces (Nyonyo et al., 2014). In special cases, like in our study, Shigella genus isolates from the ruminal environment were also described (Akintokun et al., 2014; Baltaci and Adiguzel, 2016; Wang et al., 2011).

Most cellulolytic microorganisms isolated from the rumen are Gram positive (ex. R. flavefaciens and R. albus) (Russell et al., 2009). In contrast, the bacterial strain isolated in this study is a Gramnegative coco bacillus, according with Penatti et al. (2007), of the genus Shigella.

Ruminal microorganisms hydrolyze structural carbohydrates and use monosaccharides and disaccharides for their growth, in addition to other derivatives from fermentation of structural 
polysaccharides. Shigella sp, isolated from the ruminal ecosystem, releases endoglucanase and xylanase enzymes (Baltaci and Adiguzel, 2016) to metabolize residual cell wall components such as cellulose, cellobiose and xylose (Wang et al., 2011). The presence of halos is an indicator of extracellular production of cellulase (Gupta et al., 2012; Baltaci and Adiguzel, 2016). Endogluconase activity was also observed in bacteria growing in Petri dishes, pressumably because the dye is absorbed by polysacharidic bacterial chains (Ten et al., 2004).

Although API WEB software was not compatible for identifying this microorganism, it evaluated the metabolic activity of the strain, mostly the cellulolytic activity. The ability to ferment glycerol, ribose, D-xilose, sucrose, galactose, glucose, fructose, manose, maltose, mannitol, sorbitol, among others, is in agreement with characteristics reported by Wang et al. (2011) for the genus Shigella.

Few molecular studies have found new bacterial species in the rumen; it is more common to recognize unidentified fungi genera. Many non-identified species are not phenotypically characterized (Tamura et al., 2007). It is also noticeable that many $16 \mathrm{~S}$ rRNA gene sequences did not show similarity with classified bacteria, which could lead to the development of livestock specific phylotypes.

Molecular identification based on 16S rRNA or 16S rDNA sequencing (Deng et al., 2008; Mosoni et al., 2007) provides valuable information about the presence of new species in different habitats (Ten et al., 2004), particularly in the rumen (Wang et al., 2011). Fonty et al. (2007) reported a microorganism closely related to Shigella boydii ( $98.2 \%$ identitiy, $16 \mathrm{~S}$ rRNA sequence) in samples isolated from gnotobiotic lambs inoculated with functional ruminal microbiota, and Akintokun et al. (2014) identified species of Shigella genus in ruminal samples from Nigerian breeds of cattle, congruent with our results.

Besides, cellulolytic activity was reported in bacteria of the Shigella genus isolated from the rumen through traditional microbiological processes in culture media selective for cellulolytic ruminal bacteria (Baltaci and Adiguzel, 2016), and pure isolates were identified by phenotypic characterization (colonial and microscopic morphology). This is relevant for further studies about substrate metabolism and the use of genetic techniques that mark a turning point in the analysis of isolated microbial species (Kenters et al., 2011; Creevey et al., 2014).

We conclude that the isolated bacterium is as a member of the genus Shigella, based on the 16S rDNA sequencing, which is in agreement with its ability to hydrolyze structural carbohydrates. Due to the inability of this strain to degrade cellobiose, based on API 50 strips test, additional studies are needed to further characterize the specific mechanisms of cellulose metabolism The isolated bacterium is an interesting candidate for obtaining oligosaccharides from lignocellulosic biomass.

\section{Aknowledgments}

This study was supported by LPI-5 Microbial, Vegetal and Animal Biotechnology, Colegio de Postgraduados, Montecillo, Estado de Mexico.

\section{Conflict of interest}

The authors declare they have no conflicts of interest with regard to the research presented in this report.

\section{References}

Akintokun AK, Adeyosoye OI, Abiola-Olagunju O, Joel EO. Identification and occurrence of heterophilic rumen bacteria and fungi isolated from selected Nigerian breeds of cattle. Appl Environ Microbiol 2014; 2(6):303-308.

Artzi L, Bayer EA, Moraïs S. Cellulosomes: bacterial nanomachines for dismantling plant polysaccharides. Nature Reviews Microbiology 2016;15:83-95.

Baltaci MO, Adiguzel A. Isolation, identification and molecular characterization of cellulolytic bacteria from rumen samples collected from Erzurum slaughter house, Turkey. Res J Biotech 2016; 11(2):32-38.

Boots B, Lillis L, Clipson N, Petrie K, Kenny D, Boland T. Responses of anaerobic rumen fungal diversity (phylum Neocallimastigomycota) to changes in bovine diet. J Appl Microbiol 2013; 114:626-635.

Creevey CJ, Kelly WJ, Henderson G, Leahy SC. Determining the culturable accessibility of the rumen bacterial microbiome. Microb Biotechnol 2014; 7:467-479. 
Cobos MA. Clostridium paraputrificum var. Ruminantium: Colonization and degradation of shrimp carapaces in vitro observed by scanning electron microscopy. In: Wallace RJ and Lahlou-Kassi A, editors. Rumen Ecology Research Planning. Procedings of a Workshop Held at ILRI. Addis Ababa, Ethiopia: International Livestock Research Institute; 1995.

Deng W, Xi D, Mao H, Wanapat M. The use of molecular techniques based on ribosomal RNA and DNA for rumen microbial ecosystem studies: a review. Mol Biol Rep 2008; 35(2):265-274.

Denman SE, McSweeney CS. The early impact of genomics and metagenomics on ruminal microboilogy. Ann Rev Anim Biosci 2015; 3:447-465.

Dias J, Marcondes MI, Noronha MF, Resende RT, Machado FS, Mantovani HC, Suen G. Effect of pre-weaning diet on the ruminal archaeal, bacterial, and fungal communities of dairy calves. Front Microbiology 2017; 8:1553-1570.

Flint HJ, Bayer EA. Plant cell wall breakdown by anaerobic microorganisms from the mammalian digestive tract. Ann NY Acad Sci 2008; 1125:280-288.

Flint HJ, Bayer EA, Lamed R, White BA. Polysaccharide utilization by gut bacteria: potential for new insights from genomic analysis. Nature Rev Microbiol 2008; 6:121-131.

Fonty G, Joblin K, Chavarot M, Roux R, Naylor G, Michallon F. Establishment and development of ruminal hydrogenotrophs in methanogen-free lambs. Appl Environ Microbiol 2007; 73(20): 6391-6403. http://aem.asm.org/content/73/20/6391.full.pdf.

Forbes C, Hughes D, Fox J, Ryan P, Colleran E. Highrate anaerobic degradation of 5 and 6 carbon sugars under thermophilic and mesophilic conditions. Bioresour Technol 2010; 101(11):3925-3930.

Gharechahi J, Zahiri HS, Noghabi KA, Salekdeh GH. In-depth diversity analysis of the bacterial community resident in the camel rumen. Syst Appl Microbiol 2015; 38(1):67-76.

Gupta P, Samant K, Sahu A. Isolation of cellulose-degrading bacteria and determination of their cellulolytic potential. Int J Microbiol 2012; Article ID 578925:1-5. http://dx.doi. org/10.1155/2012/578925.

Guzman CE, Bereza-Malcolm LT, De Groef B, Franks AE. Uptake of milk with and without solid feed during the monogastric phase: effect on fibrolytic and methanogenic microorganisms in the gastrointestinal tract of calves. Anim Sci J 2016; 87:378-388.

Hatful GF, Jacobs Jr WR. Molecular Genetics of Mycobacteria. 2a ed. Washington, DC: American Society for Microbiology Press; 2014.

Kenters N, Henderson G, Jeyanathan J, Kittelmann S, Janssen $\mathrm{PH}$. Isolation of previously uncultured rumen bacteria by dilution to extinction using a new liquid culture medium. J Microbiol Methods 2011;84:52-60.

Ley de-Coss A, Arce EC, Cobos PM, Hernández SD, Pinto RR. Estudio comparativo entre la cepa de Pediococcus acidilactici aislada del rumen de borregos y un consorcio de bacteria ruminales. Agrociencia 2013; 47:567-578.

Mateo-Sánchez JM, Cobos-Peralta MA, Trinidad-Santos A, Cetina-Alcalá V, Vargas-Hernández J. Aislamiento de bacterias ruminales degradadoras del aserrín. Agrociencia 2002; 36(5): 523-530. http://www.redalyc.org/articulo.oa?id=30236503.

Mosoni P, Chaucheyras-Durand F, Béra-Maillet C, Forano E. Quantification by real-time PCR of cellulolytic bacteria in the rumen of sheep after supplementation of a forage diet with readily fermentable carbohydrates: effect of a yeast additive. J Appl Microbiol 2007; 103(6):2676-2685.

Newbold CJ, de la Fuente G, Belanche A, Ramos-Morales E, McEwan NR. The role of ciliate protozoa in the rumen. Front Microbiol 2015; 6:1313-1322.

NOM-062-ZOO. 1999. Norma Oficial Mexicana. Especificaciones técnicas para la producción, cuidado y uso de los animales de laboratorio. http://www.fmvz.unam.mx/fmvz/ principal/ archivos/062ZOO.PDF.

Nyonyo T, Shinkai T, Tajima A, Mitsumori M. Effect of media composition, including gelling agents, on isolation of previously uncultured rumen bacteria. Lett Appl Microbiol 2013; 56:63-70.

Penatti MPA, Hollanda LM, Nakazato G, Campos TA, Lancellotti M, Angellini M, Brocchi M, Rocha MM, Dias da Silveira W. Epidemiological characterization of resistance and PCR typing of Shigella flexneri and Shigella sonnei strains isolated from bacillary dysentery cases in Southeast Brazil. Braz J Med Biol Res 2007; 40(2): 249-258. http://www.scielo.br/scielo.php?script=sci arttext\&pid=S0100-879X2007000200012.

Rakotoarivonina H, Larson MA, Morrison M, Girardeau JP, Gaillard-Martinie B, Forano E, Mosoni P. The Ruminococcus albus pilA1-pilA2 locus: expression and putative role of two adjacent pil genes in pilus formation and bacterial adhesion to cellulose. Microbiol 2005; 151:1291-1299.

Russell JB, Muck RE, Weimer PJ. Quantitative analysis of cellulose degradation and growth of cellulolytic bacteria in the rumen. FEMS Microbiol Ecol 2009; 67(2):183-197. http:// mic.microbiologyresearch.org/content/journal/micro/10.1099/ mic. $0.27735-0$

Samsudin AA, Wright ADG, Jassim RA. Cellulolytic bacteria in the foregut of the dromedary camel (Camelus dromedarius). Appl Environ Microbiol 2012; 78(24):8836-8839. http://aem.asm.org/ content $/ 78 / 24 / 8836$.full.

Singh KM, Jisha TK, Reddy B, Parmar N, Patel A, Patel AK, Joshi CG. Microbial profiles of liquid and solid fraction associated biomaterial in buffalo rumen fed green and dry roughage diets by tagged 16S rRNA gene pyrosequencing. Mol Biol Rep 2015; 42(1):95-103.

Slutzki M, Jobby MK, Chitayat S, Karpol A, Dassa B, Barak Y, Lamed R, Smith SP, Bayer EA. Intramolecular clasp of the cellulosomal Ruminococcus flavefaciens ScaA dockerin module confers structural stability. FEBS Open Bio 2013; 3:398-405. http://www.ncbi.nlm.nih.gov/pmc/articles/PMC3821032/. 
Tamura K, Dudley J, Nei M, Kumar S. MEGA4: Molecular evolutionary genetics analysis (MEGA) software version 4.0. Mol Biol Evol 2007; 24(8):1596-1599. http://mbe.oxfordjournals.org/ content/24/8/1596.long.

Ten LN, Im WT, Kim MK, Kang MS, Lee ST. Development of a plate technique for screening of polysaccharide-degrading microorganisms by using a mixture of insoluble chromogenic substrates. J Microbiol Methods 2004; 56(3):375-382.

Valledor L, Escandón M, Meijón M, Nukarinen E, Cañal MJ, Weckwerth W. A universal protocol for the combined isolation of metabolites, DNA, long RNAs, small RNAs, and proteins from plants and microorganisms. Plant J 2014; 79(1):173-180. http:// onlinelibrary.wiley.com/doi/10.1111/tpj.12546/pdf.

Venkatesh B. Current challenges in commercially producing biofuels from lignocellulosic biomass. ISRN Biotechnology 2014; Article ID 463074:31. http://dx.doi.org/ 10.1155/ 2014/463074.

Wanapat M, Cherdthong A. Use of real-time PCR technique in studying rumen cellulolytic bacteria population as affected by level of roughage in swamp buffalo. Curr Microbiol 2009;
58(4):294-299. http://link.springer.com/article/10.1007\%2 Fs00284-008-9322-6\#/page-1.

Wang A, Gao L, Ren N, Xu J, Liu C, Cao G, Yu H, Liu W, Hemme $\mathrm{CL}, \mathrm{He} \mathrm{Z}$, Zhou J. Isolation and characterization of Shigella flexneri G3, capable of effective cellulosic saccharification under mesophilic conditions. Appl Environ Microbiol 2011; 77(2):517-523. http://aem.asm.org/content/77/2/517.long.

Weimer PJ, Price NPJ, Kroukamp O, Joubert LM, Wolfaardt GM, Van Zyl WH. Studies of the extracellular glycocalyx of the anaerobic cellulolytic bacterium Ruminococcus albus 7. Appl Environ Microbiol 2006; 72(12):7559-7566. http://aem.asm.org/ content/72/12/7559.full.

Wilson DB. Microbial diversity of cellulose hydrolysis. Curr Opin Microbiol 2011; 14:259-263.

Zhivin O, Dassa B, Moraïs S, Utturkar SM, Brown SD, Henrissat B, Lamed R, Bayer EA. Unique organization and unprecedented diversity of the Bacteroides (Pseudobacteroides) cellulosolvens cellulosome system. Biotechnol Biofuels 2017; 10:211-218 